\title{
OPEN BUILDING CONCEPT FOR FISHERMAN HOUSING ON THE NORTH COASTAL SURABAYA
}

\author{
Ima Defiana ${ }^{1^{*}}$, Angger Sukma Mahendra ${ }^{1}$ \\ ${ }^{1}$ Department of Architecture, Institut Teknologi Sepuluh Nopember, \\ Kampus ITS, Sukolilo, Surabaya 60111, INDONESIA \\ *Corresponding author; Email: imadefiana1@gmail.com
}

\begin{abstract}
One of global warming impacts is sea levels rising. Fisherman settlements on the North coastal Surabaya is one of built enviromment that is affected by the threat from sea levels rising. Addtionally, this settlements faces severeal environmental problems including slums and housing density. Yet, this paper is limited only discussed the influence of fish processing activity area with the minimum housing area. The aim of study provides an alternative solution to these problems and to achieve feasible and sustainable fisherman settlements. The descriptive qualitative is used as a research method. The field survey was used to obtain data for design concept supports. Results shows the current location has still fit as fisherman settlement, then the open building concept is proposed to redesign fisherman housings. This design concept offers two aspects, namely adaptation and flexibility. The result shows that the concept of a vertical single housing unit in which is owened by single (one) family, which is fit with the limited area, approximately 28 square meters.
\end{abstract}

Keywords: Housing; Nambangan; open building; slum area.

\section{INTRODUCTION}

Until now, global warming is a topic that discusses frequently which effect on the sea level. The consequence of it is sea level rising. Higher sea level may endanger the fisherman settlement, including the settlement in the north coastal area of Surabaya. Slums and housing density become the main issues, including limited spaces for fishing processing activity and the domestic activity (Defiana, 2016). Fishermen settlements of North coastal Surabaya is selected as an object of research to support the government's plan Surabaya (Surabaya fisherman settlement arrangement of residential areas). This area is designed to support tourism area on the North coastal Surabaya (BAPEKO, 2014), has been supported by several facilities such as the Sentra Fish Market Bulak, Kenjeran Ria Beach etc.

The aim of study provides an alternative fishermen settlements concept to solve problems due to sea level rising, slum and housing density. The proposed concept is based on an open building, that emphasizes users orientation, also offers flexibility space and user's adaptability (Kendall \& Teicher, 2000). The flexibility of function spaces and adaptability of inhabitants could support their activities. Finally, the design concept will provides healthier environment also supports economic independency that may reduce than before in order avoiding slums. Futhermore the fisherman settlements is designed to provide production space for fish processing, such as repairing nets room, drying room etc. Production space should be accessible to women and could increase economic independency (Cahyadini \& Defiana, 2013). In this study, by recognizing the inhabitants' space adaptability, the production space is provided. Thus, it will promote the economic growth that affects on the sustainability of the fisherman settlement itself.

The government of Senegal is one of best precedent for the economic success based on fishing communities. The government has effort to tackle slums of fisherman settlement by strengthening economic system based on local community strengthening or called CBFM (community-based fisheries management). This includes data CBFM fishing season in general, the arrangement of the control of fishing services and marketing, management training catches. CBFM has been implemented in some fishing villages prospers. The point is based on local knowledge and local community initiatives (Watanuki, 2004).

\section{METHODOLOGY}

This study uses field studies as a tool for reading the phenomenon in the field. Field observations are conducted in July-August. July-August is the dry season in Surabaya. Field observations aimed to determine the physical characteristics of housing, infrastructure and activities of the occupants.

The research location is in the region of North Surabaya. North Surabaya region is divided into 
inland and coastal areas. One of them is the District of Bulak. In a district administration Bulak village divided into 5 areas namely Kenjeran Complex Village, Sukolilo Village, Kenjeran Village, Bulak village, Kedung Cowek Village (www.organisasi. org). Kedung Cowek Village is one of the villages that have coastal administrative regions. One of them is Nambangan.

The data of physical housing characteristics and occupant activities obtained through questionnaires. The selection of respondents is done by purposive sampling method. One of the criteria for the selection of respondents is the location of the housing on the coastal, near the seaside or bordered by beach and occupants have main activity as fisherman with additional activities. Based on the criteria set 38 respondents are selected purposively. The number of respondents represents the condition of occupancies in the North coastal of Surabaya which is relatively homogeneous.

\section{RESULTS AND DISCUSSION}

The observed field conditions show that fishing settlement located on the waterfront and some alley directly opposite the coastal (see figure 1). Nambangan coastal classified as a gently slope beach, is located in the Madura Strait. Based on these conditions, the existing location provides opportunities occupancy arrangement fishermen overlooking the coastal to obtain better sea breeze..

Waterfront settlement patterns according Soesanti et al. (2006) and Hasan (2010) are classified into three, namely a linear pattern, a radial pattern, and the pattern of concentric design branch. This pattern classification is formed based on the topography characteristic. The coastal settlement usually developed as linier settlement pattern follows the coastline that live on the coast generally elongated shape following the shoreline. This shape is influenced by the pattern of activity of the population of fisherman. Settlement patterns of coastal Nambangan, Kenjeran, Surabaya is elongated along the northern coastline. Nambangan settlement patterns on the coastal can be divided into two types. Type 1 represents the settlement which is directly overlooking the coastal. Type 2 is the settlements overlooking the alley that is connected with the coastal, as shown in figures 2 and 3 .

Based on land use regulation as shown in fig. 4, the current location are marked as a residential area (yellow) and services (pink). Therefore, the location study is the same as the existing one, yet improving the housing quality is needed.

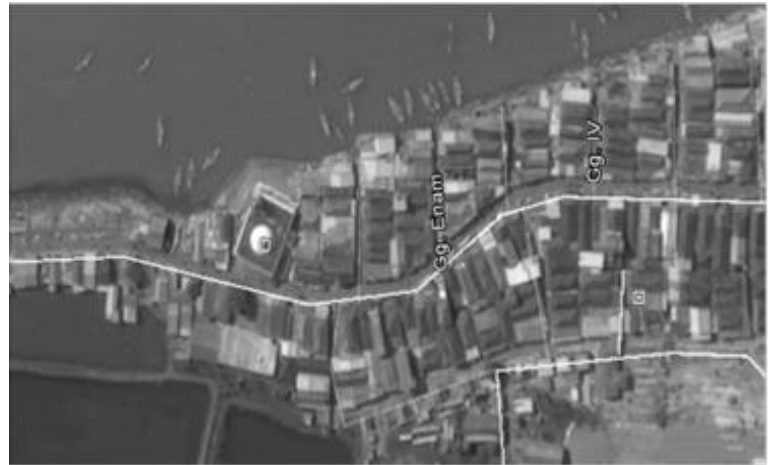

Fig. 1. Settlement in Nambangan, Surabaya (www.googleearth.com)

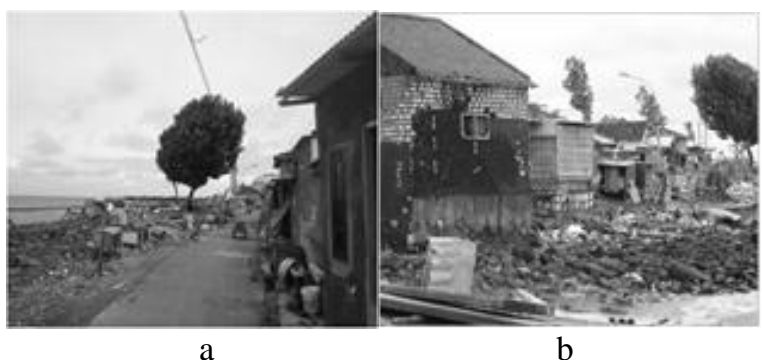

Fig. 2. Type 1 Settlement (Defiana et al, 2016)

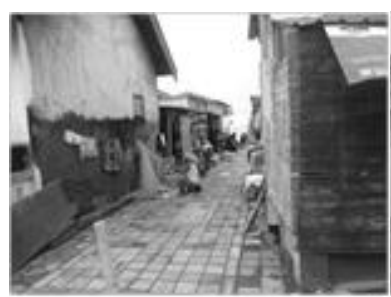

a

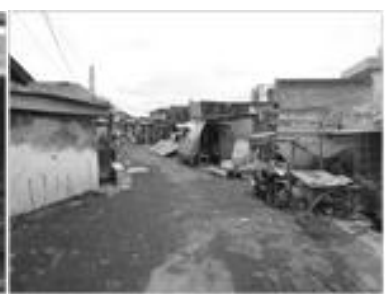

b
Fig. 3. Type 2 Settlement (Defiana et al, 2016)

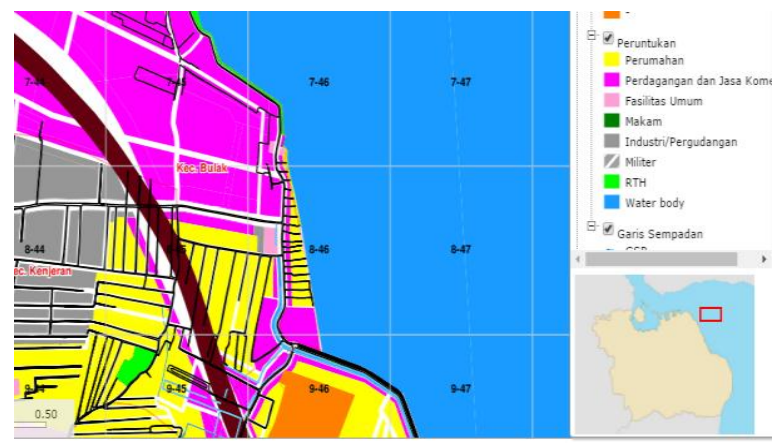

Fig. 4. Land Use Regulation (www.petaperuntukan.surabaya.go.id)

The first stage of design process is a site analysis. Next, design criteria are determined and followed by proposing schematic design concept, and finally a schematic design. Site analysis is based on the suitability of the site as a condition of the existing residential area, based on regulations, its weaknesses and ecological potential. The location of settlements is 
analyzed based on several aspects considered. Those aspects are the physical and the environmental aspects of the residential area fishermen taken from regulation made by the Department of Public Works. Those aspects are not located in disaster-prone areas, not in area coastline and riverbank, minimum slopes between $0-25 \%$ with horizontal orientation of coastline should be more than 60 degree. Moreover, the location should have flatter with gentle basic slope with relict sediment of gravel and fine sand, have less erotion of mainland beaches with mild sea wave and tidal, not in the protected or conservation area including in the mangrove for coastal defence. Additonally the location is accessible for the transport network. Based on these criteria, the current location meet the criteria and corresponding to redesign residential fishing communities that have been living around Nambangan, Kenjeran, Surabaya.

In general, the activity of people who live in fishermen on settlement of the northern coastal of Surabaya is fishermen, ie fishing, processing the catch, drying fish, mend nets etc. In the Nambangan coastal area fish processing is done in front of their houses or in the alley. As a result, the activity causes unpleasant scent and even become worse the drainage and sewer do not function properly. Even in some locations such as shown in fig. 5, the drain line and sewer are not available. After processing the fish, the next activity is the drying process. As seen in the fig. 5 , the process of drying is placed in front of fishermen's house. If drying the fish under the sun is not sufficient, this process will cause pungent smell. The pungent smell becomes worst when the wind flow directly to drying area, especially in the afternoon. Based on the analysis of activity patterns of fishermen and their families, space is provided to. Suppose to be provided space to mend the nets, catch to process fish processing space and so on.

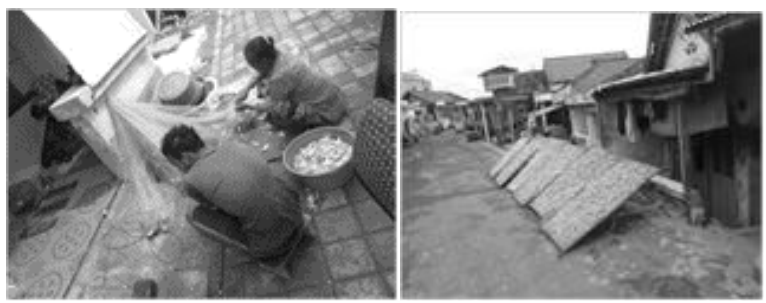

Fig. 5. Activities of Fisherman and His Family (Defiana et al, 2016)

As described above, in general the fishing settlement of the northern coastal of this Nambangan follows the shoreline (type 1 settlement). Type 2 of settlement is divided into several alleys. The houses are facing the alley. The fishing settlement has great density impinges on each other, as a result the chances of getting the daylight and natural ventilation are less.

Nambangan fishing settlement has a potential to be developed into habitable a fishing settlement. The only requirement is the concept of settlement arrangement. In principle fishing settlement has the potential for high sea breeze occurance. However, with higher wind velocity will impact higher air carries pollutants as well, such aspecially for unpleasant smell from fishing processing with poor drains system. Therefore it is necessary to improve the drainage or drains in the neighborhood.

Related to the position of the ground water level which is high in coastal areas will require special technology to handle waste from the toilet. This should be done to avoid damage or contaminate groundwater. Therefore we need a communal wastewater treatment. Town Planning Board (BAPEKO) Surabaya had planned positions communal wastewater treatment for settlements overlooking the alley (see figure 6).

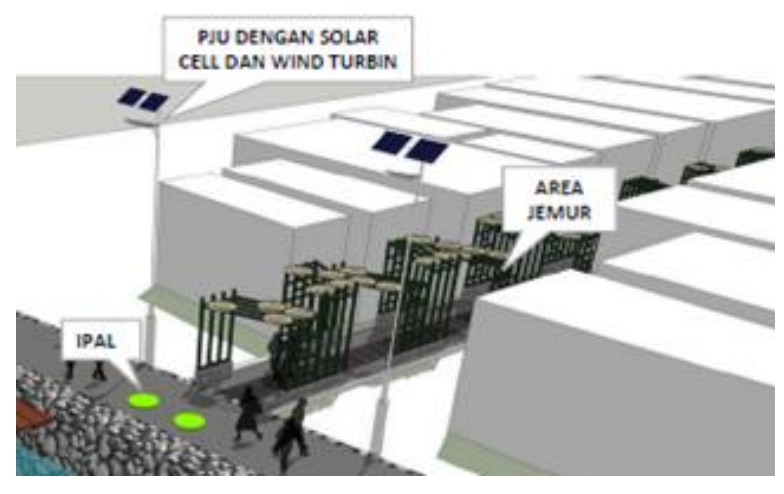

Fig. 6. Illustration of Drying Process Facilities and Waste Water Treatment in Fisherman Settlement (BAPEKO Surabaya, 2014)

In contrast with the concept proposed by BAPEKO Surabaya, the study proposes the concept of settlement overlooking the coastline. Thus it can be obtained in the settlement arrangement of Nambangan beach holistically, by adopting BAPEKO design and proposed design.

After site analysis, next stage is set the design criteria. Based on field studies, three design criteria are obtained, namely:

1. Criteria for outer space

2. Criteria for building physical. 1) adaptability: the ability of residents to adapt from the landed house to multi-storey house. 2) flexibility: the ability of residents to organize partitions in the housing according to their needs. 3) providing business spaces so that in case of high wind season, fishermen still generate revenue. 
3. Design of ecological response to the environment. Changing habituation sanitation and environment towards a more hygienic.

Design criteria are obtained based on field study. It aims to be able to provide flexible space requirement on the activities, adaptation from landed house to multi storey. Therefore housing can be expected to adapt for climate change. Thus the housing will be a continuous occupancy or sustainable.

Based on the specified design criteria, the design concept is developed based on open building context, especially related to how occupant adapts and function the space in limited area. It aims to ensure that the design decisions taken will give a good impact on the future because it is planned based on the change and stability area. In general, open building is in contrast to conventional buildings. In the open building consider the changing needs of its inhabitants in the future. Additionally, other changes that should be addressed in the design of open building include dynamic environmental factors such as thermal, acoustics, lighting, and building performance.

One of the principles of open building is to prepare the base building and infill. The facilities in the base building are a structure system and utilities system. While the infill in building is open partitions required by the occupants. Besides designed in the context of open building was attentive to local climatic conditions.

The proposed concept begins with the arrangement of outer space. For the arrangement of outer space give the concept of open space connected to coastal. In this paper, proposed residential concept for fishermen is aimed for housing or settlement type 1, the housing directly facing the coastal area. The main concept for housing arrangements is to provide sufficient distance for the wind flow. This distance refers to the research conducted by Oke (1988) states is the ratio of a height $(\mathrm{H})$ of the distance is between the width of building (W) or the $\mathrm{H} / \mathrm{W}$ ratio of 0.30.5 . Therefore, housing do not have elongate lined.

In contrast to other housing, the proposed concept of housing for fishermen on Nambangan coastal is prepared up for each family or single housing unit. This is a translation of the design criteria, namely adaptability. By drafting in the single family led to the occupants not to lose their privacy.

Based on the principle of open building, the first step to be prepared is a structure system and utilities system as base building (fig. 7). In this case as base building is set up residential units with an area similar to the overall settlement which is $28 \mathrm{~m} 2$. As described previously the housing concept is based on flexibility fishermen which is then is not given the massive walls, except for the master bedroom and bathroom.

The concept for the ground floor is open plan. The ground floor is by providing a space for fishermen activities, such as repairing nets, fish processing etc. Although it has been predicted is not exposed to tides, the toilet is placed on the second floor. On the second floor is used as the main room, while the third floor is used as children room (Fig. 7 and 8).

Associated to natural ventilation and daylight, the front side and the back sides of the unit has openings. Each housing is expected to become healthier and can save energy. Thus the operating expenses for the dwelling can be saved and become sustainable settlements (Fig. 9 and 10).

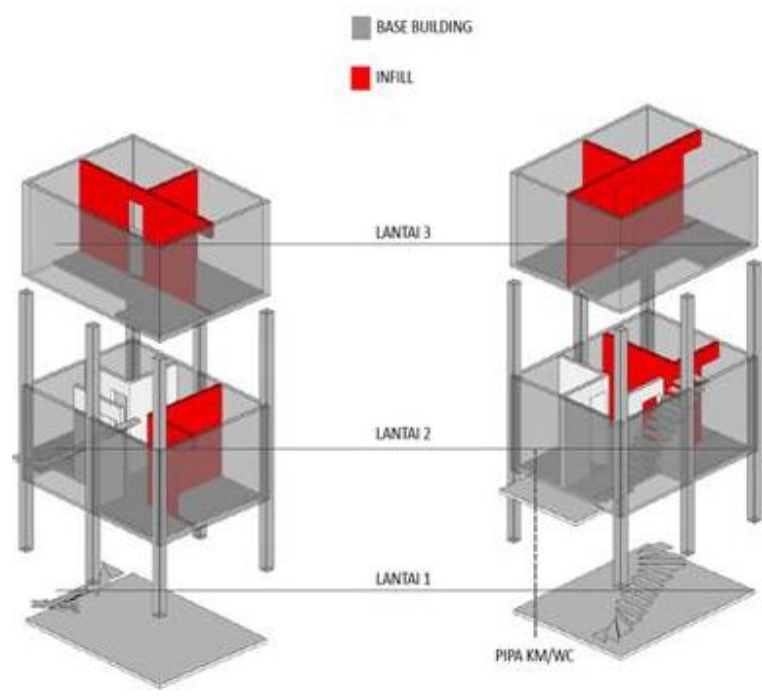

Fig.7. Isometri of Single Housing Unit

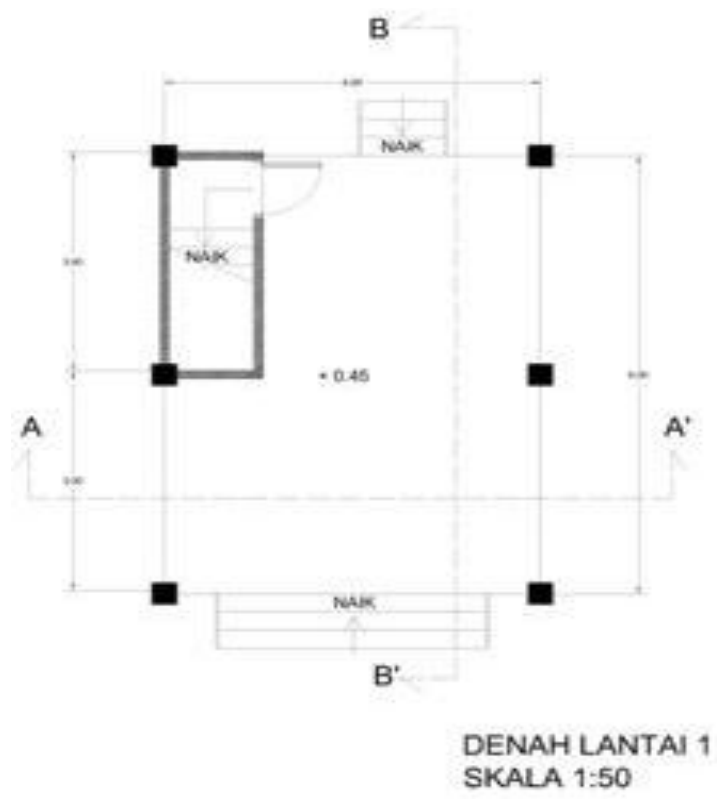




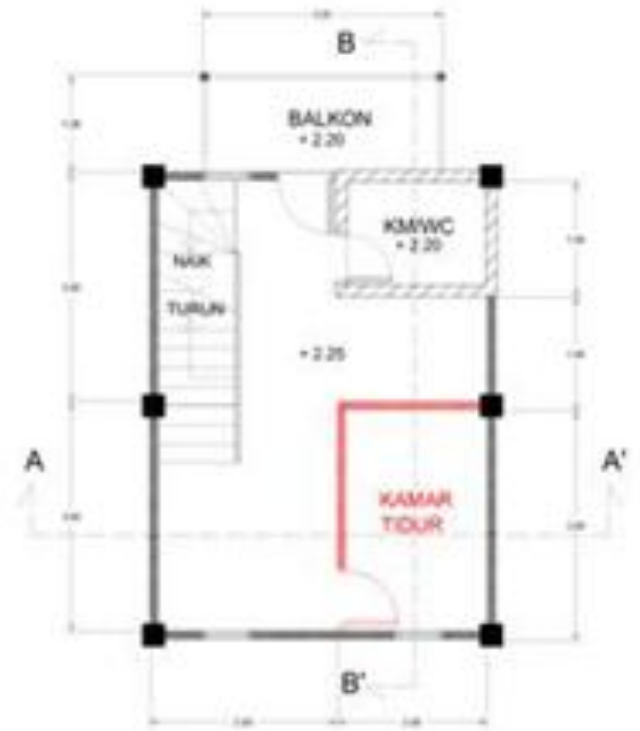

DENAH LANTAI 2 SKALA 1.50

B

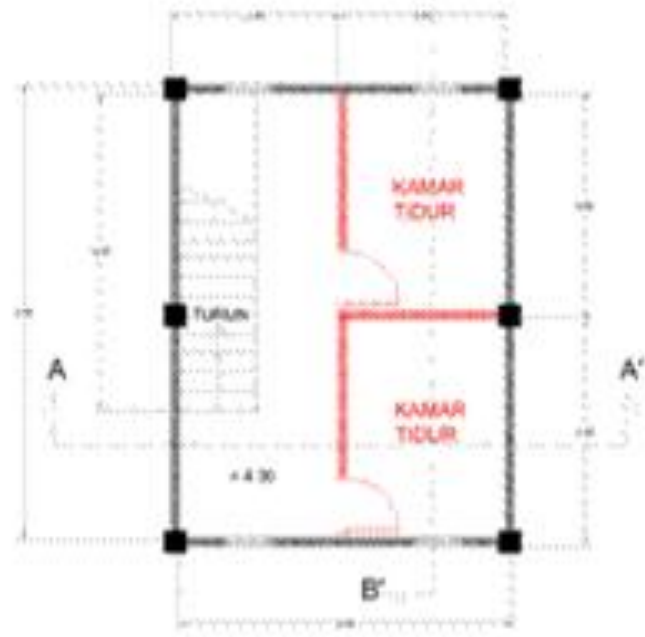

DENAHLANTAI 3

SKALA $1: 50$

Fig. 8. Plan of Single Housing Unit

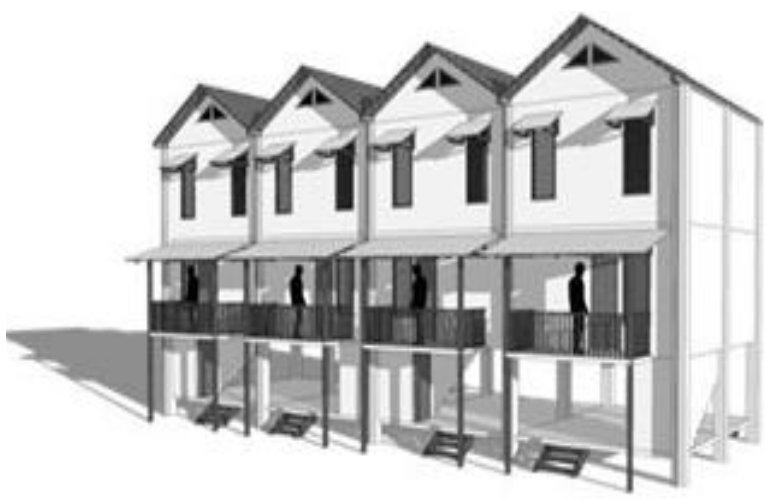

Fig. 9. Row of Single Housing Unit

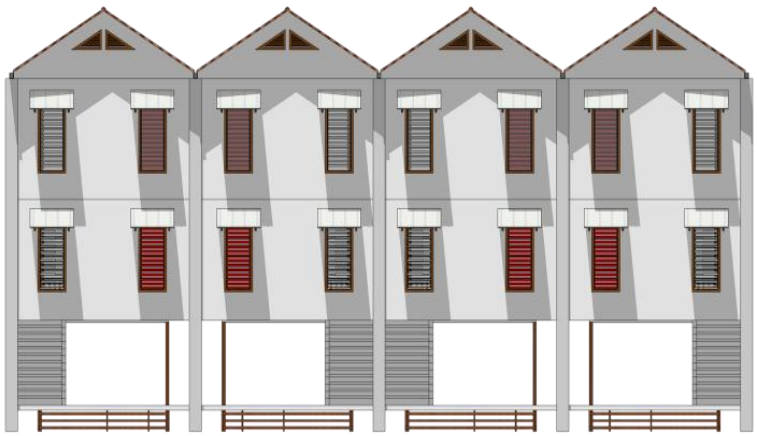

Fig. 10. Facade of Single Housing Unit Row

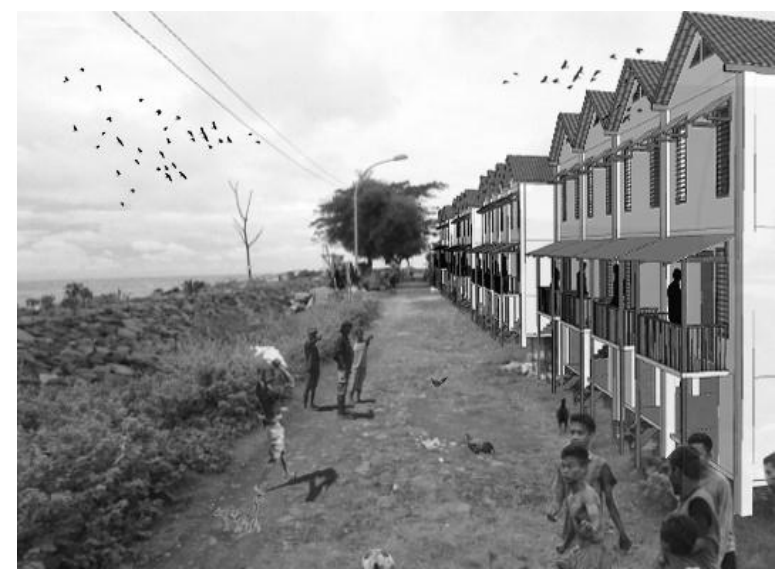

Fig. 11. Illustration of Single Housing Row Unit

\section{CONCLUSION}

The important aspect to be considered in housing design for fishermen is the adaptability and flexibility. Both are the elaboration of the theory of open building. The aspects of flexibility are associated with elements of the design such as the arrangement of the room divider. This arrangement is influenced by activity and space requirements. Aspects of adaptation are associated with the habit of fishing communities, which originally lives on landed house and that turned converted into a vertical housing or multi storey housing. In general, proposed to single housing unit is different from conventional housing. The concept of a single vertical housing unit is owned by one family, that the vertical composition does not mix with the other family.

\section{ACKNOWLEDGMENTS}

The authors would like thank to the Ministry of Higher Education Indonesia for providing research grants through Penelitian Unggulan Perguruan Tinggi (PUPT) ITS scheme and also to Wenda Pristi for providing technical support for CAD 


\section{REFERENCES}

Defiana, I. et al. (2016). Konsep Rumah Susun untuk Masyarakat Nelayan di Pantai Utara Surabaya, Penelitian Unggulan Perguruan Tinggi 2016, Jurusan Arsitektur, ITS.

Hassan, A.S. (2010). Reviews an Old City Landsacpe with Reference to Traditional Fishing Village Settlements in Western Coastal Region, Peninsular Malaysia. Journal of Human Settlemens, 2(1).

Oke, T.R. (1988). 'Street Design and Urban Canopy Layer Climate'. Energy and Building, 11, pp. 103-113,

Kendall, S. \& Teicher, J. (2000). 'Residential Open Building'. E \& FN Spon, London and New York.

Bapeko kota Surabaya (2014).
Watanuki, N. (2004). Different approaches to responsible fisheries: global standards versus local initiatives, Overseas Agro-Fisheries Consultants Co., Ltd., IIFET 2004 Japan.

Sarah, C. \& Defiana, I. (2013). Sustainability of Women Headed Household Space in Promoting the Economic Activities, Proceeding of International Conference, SB 13 Conference Dubai, Dubai 2013.

Soesanti, S. et al. (2006). Pola penataan zona, massa dan ruang terbuka pada perumahan waterfront (studi kasus: perumahan pantai indah kapuk). Jurnal Dimensi Teknik Arsitektur. 34(2), pp.115121.

www.googleearth.com

www.organisasi.org

www. petaperuntukan.surabaya.go.id 